\title{
Penerapan Algoritma Semut dalam Penentuan Distribusi Jalur Pipa Pengolahan Air Bersih
}

\author{
Agus Perdana Windarto ${ }^{\mathrm{a}}$, Sudirman ${ }^{\mathrm{b}}$ \\ ${ }^{a}$ STIKOM Tunas Bangsa Pematangsiantar \\ ${ }^{b}$ Universitas Bung Karno Jakarta \\ Naskah Diterima : 12 April 2018; Diterima Publikasi : 29 September 2018
}

DOI : 10.21456/vol8iss2pp123-132

\begin{abstract}
Pengembangan Kinerja Pengolahan Air Minum (PKPAM) is a work unit for the development of drinking water treatment performance in the Riau Islands which is responsible for fulfilling the drinking water needs of the citizens through increasing access to piping lines which will later serve the needs of water distribution to each people's home through water sources. The problem that often arises is not served the same water debit at the last node, due to the not too large discharge from the water source to serve the needs of residents. In general, the search for the shortest path becomes the solution given. The shortest path search is divided into two methods, namely the conventional method and the heuristic method. In the heuristic method there are several algorithms, one of them is the ant algorithm. The ant algorithm is an algorithm adopted from the behavior of ant colonies. Naturally, ant colonies are able to find the shortest route on the way from the nest to places of food sources. Ant colonies can find the shortest route between the nest and the food source based on footprints on the traversed path. The more ants that pass a path, the clearer the footprint will be. Ant algorithm is very suitable to be used to solve optimization problems, one of which is to determine the shortest path. This study aims to facilitate the Drinking Water Treatment Performance Development section to make a decision in determining the location of the water pipe distribution pipeline that will be channeled to the residents' homes. This research took 8 points of clean water treatment pipeline with the starting point A and the destination point $\mathrm{N}$. Based on the calculation of the determination of the clean water treatment pipeline between $\mathrm{A}$ and $\mathrm{N}$ using the ant algorithm, the cycle passed proved that the shortest path through one pipe is a pipe $\mathrm{N}$ as the destination is the 3rd route with a pipe length of 441 meters $(\mathrm{V} 1 \rightarrow \mathrm{V} 2 \rightarrow \mathrm{V} 3 \rightarrow \mathrm{V} 6 \rightarrow \mathrm{V} 7 \rightarrow \mathrm{V} 8)$.
\end{abstract}

Keywords: Shortest path search; Heuristic; Ant Algorithm; Water pipe.

\begin{abstract}
Abstrak
Pengembangan Kinerja Pengolahan Air Minum (PKPAM) merupakan satuan kerja pengembangan kinerja pengolahan air minum di Kepulauan Riau yang bertanggungjawab terhadap pemenuhan kebutuhan air minum warga melalui peningkatan akses jalur perpipaan yang nantinya jalur tersebut dapat melayani kebutuhan distribusi air ke setiap rumah warga melalui sumber air. Permasalahan yang sering muncul adalah tidak terlayani debit air yang sama pada node terakhir, dikarenakan debit yang tidak terlalu besar dari sumber air untuk melayani kebutuhan warga. Secara umum pencarian jalur terpendek menjadi solusi yang diberikan. Pencarian jalur terpendek dibagi menjadi dua metode, yaitu metode konvensional dan metode heuristik. Pada metode heuristik terdapat beberapa algoritma, salah satunya algoritma semut. Algoritma semut adalah algoritma yang diadopsi dari perilaku koloni semut. Secara alamiah koloni semut mampu menemukan rute terpendek dalam perjalanan dari sarang ke tempat-tempat sumber makanan. Koloni semut dapat menemukan rute terpendek antara sarang dan sumber makanan berdasarkan jejak kaki pada lintasan yang telah dilewatii. Semakin banyak semut yang melewati suatu lintasan, maka akan semakin jelas bekas jejak kakinya. Algoritma Semut sangat tepat digunakan untuk diterapkan dalam penyelesaian masalah optimasi, salah satunya adalah untuk menentukan jalur terpendek. Penelitian ini bertujuan untuk memudahkan bagian Pengembangan Kinerja Pengolahan Air Minum mengambil keputusan dalam menentukan titik lokasi pemasangan pipa distribusi saluran air yang nantinya disalurkan ke rumah warga. Penelitian ini mengambil 8 titik jalur pipa pengolahan air bersih dengan titik awal A dan titik tujuan N. Berdasarkan perhitungan penentuan jalur pipa pengolahan air bersih antara A dan $\mathrm{N}$ dengan menggunakan algortima semut, dari siklus yang dilewati terbukti bahwa jalur terpendek yang melewati satu pipa yaitu pipa $\mathrm{N}$ sebagai tujuan dengan adalah rute ke 3 dengan panjang pipa 441 meter $(\mathrm{V} 1 \rightarrow \mathrm{V} 2 \rightarrow \mathrm{V} 3 \rightarrow \mathrm{V} 6 \rightarrow \mathrm{V} 7 \rightarrow \mathrm{V} 8)$.
\end{abstract}

Kata kunci: Pencarian jalur terpendek; Heuristik; Algoritma Semut; Pipa air.

*) Penulis korespondensi: agus.perdana@amiktunasbangsa.ac.id 


\section{Pendahuluan}

Pengembangan Kinerja Pengolahan Air Minum (PKPAM) yang dikelola Satuan kerja pengembangan kinerja pengolahan air minum Kepulauan Riau dalam rangka percepatan peningkatan pemenuhan kebutuhan air minum salah satunya meliputi peningkatan akses melalui perpipaan, dimana pipa-pipa distribusi tersebut yang nantinya dapat melayani sambungan ke setiap rumah (SR) dari pipa yang didistribusikan dari sumber Air. Adapun penyebab permasalahan yang sering muncul adalah tidak terlayani debit air yang sama pada node terakhir, dikarenakan debit yang tidak terlalu besar dari reservoir untuk melayani kebutuhan warga. Terkait uraian diatas peneliti mengambil lokasi penelitian pada Pengembangan Kinerja Pengolahan Air Minum (PKPAM) yang dikelola Satuan kerja pengembangan kinerja pengolahan air minum Kepulauan Riau. Permasalah tersebut pada jalur pemasangan pipa dimana pemasangan jalur pipa tersebut panjang dan bercabang dengan debit air yang terbagi. Sehingga memerlukan waktu yang panjang untuk mencapai titik terakhir hingga air yang keluarpun tidak maksimal. Banyak cabang ilmu komputer yang dapat menyelesaikan permasalahan yang bersifat kompleks. Hal ini terbukti dari penelitian terdahulu oleh para peneliti dalam menyelesaikan permasalahan dalam bidang data mining (Windarto 2017a, 2017b), (Sadewo et al., 2017). Dalam bidang jaringan saraf tiruan (Sumijan et al., 2016); (Siregar, 2017); (Solikhun et al., 2017); (Windarto et al., 2017). Dalam bidang sistem pendukung keputusan (Putrama dan Windarto, 2018); (Zer dan Windarto, 2018). Maka dengan melihat permasalahan yang diuraikan diatas peneliti bermaksud untuk membuat sebuah penerapan artificial intelligence dalam mengoptimasi jalur pemasangan pipa air bersih. Salah satunya adalah algoritma semut. Diharapkan algoritma semut ini dapat memberikan optimasi jalur terpendek.

Penelitian yang dilakukan Ikhsan (2016) tentang optimasi penerapan algoritma semut dalam menentukan rute tercepat dalam penjemputan barang pada tempat jasa, menjelaskan bahwa algoritma tersebut dapat memaksimalkan rute penjemputan barang titipan pada lion expres. Dalam hal ini koloni semut dapat menemukan rute terpendek antara sarang dan sumber makanan berdasarkan jejak kaki pada lintasan yang telah dilewati, semakin banyak semut yang melintasi suatu lintasan, maka akan semakin jelas bekas jejak kakinya. Istilah TSP (Traveling Salesman Problem) menurut Biggs (1986) dalam bukunya yang berjudul The Traveling Salesman Problem A Guided Tour of Combinatorial Optimization, dijelaskan bahwa permasalah yang dihadapi seorang salesman dalam menemukan lintasan paling pendek yang dapat ditempuh ke semua kota pelanggan. Dalam buku ini juga diceritakan bagaimana seorang salesman tersebut hanya boleh mengunjungi sekali untuk semua kota pelanggan dalam tiap tournya. TSP dapat direpresentasikan ke dalam permasalahan Graf. Tiap kota diwakili oleh node dalam koordinat kartesian. Tiap node mempunyai koordinat $(\mathrm{x}, \mathrm{y})$, dan semua node tersebut saling terhubung satu dengan lainnya dengan jarak masing-masing node dapat dihitung dari koordinatkoordinat nodenya. Pada penelitian (Greco, 2008); (Yuwono et al., 2009); (Nugroho, 2015); (Ismail dan Herdjunanto, 2012) juga membahas bagaimana menyelesaikan permasalahan jalur optimasi.

Berdasarkan permasalahan tersebut, penulis mengangkat topik menggunakan algoritma semut dimana algoritma dapat digunakan untuk mencari jalur terpendek dari sejumlah jalur yang digunakan pada penentuan distribusi jalur pipa pengolahan air bersih yang dikelola Satuan kerja pengembangan kinerja pengolahan air minum Kepulauan Riau, sehingga dari hasil penelitian ini dapat memberikan alternatif jalur optimal pada distribusi aliran air bersih yang nantinya dapat melayani sambungan ke setiap rumah (SR) dari pipa yang didistribusikan dari sumber Air secara optimal.

\section{Kerangka Teori}

\subsection{Kecerdasan Buatan (Artificial Intelligence)}

Kecerdasan Buatan merupakan bidang studi yang didasarkan pada premis bahwa pemikiran cerdas dapat dianggap sebagai bentuk perhitungan yang dapat diformalkan dan akhirnya dimekanisasi dengan mer representasi pengetahuan dan memanipulasi pengetahuan (Windarto et al., 2017). Dalam hal ini algoritma semut merupakan bagian kecerdasan buatan yakni Kecerdasan komputasional (Computational Intelligence).

\subsection{Teori Dasar Graf}

Graf merupakan suatu pasangan himpunan dimana simpul pada Graf dapat menyatakan objek sembarang seperti kota, atom-atom suatu zat, komponen alat elektronik, nama suatu objek dan sebagainya yang dinomori dengan huruf. Graf biasanya ditulis dengan notasi $\mathrm{G}=(\mathrm{V}, \mathrm{E})$, dimana $\mathrm{V}$ merupakan himpunan tidak-kosong dari simpulsimpul dan E merupakan himpunan sisi yang menghubungkan sepasang simpul (Munir, 2005). Jika e adalah sisi yang menghubungkan simpul u dengan simpul v maka $\mathrm{e}=(\mathrm{u}, \mathrm{v})($ Gambar 1$)$.

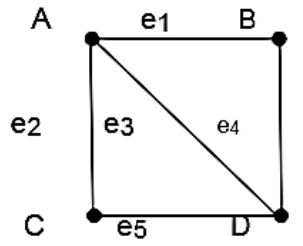

Gambar 1. Graf G $(4,5)$

G $(4,5)$ adalah Graf dengan himpunan simpul V dan himpunan sisi E adalah: 


$$
\begin{aligned}
\mathrm{V} & =\{\mathrm{A}, \mathrm{B}, \mathrm{C}, \mathrm{D}\} \\
\mathrm{E} & =\{(\mathrm{A}, \mathrm{B}),(\mathrm{A}, \mathrm{C}),(\mathrm{A}, \mathrm{D}),(\mathrm{B}, \mathrm{D}),(\mathrm{C}, \mathrm{D})\} \\
& =\{\mathrm{e} 1, \mathrm{e} 2, \mathrm{e} 3, \mathrm{e} 4,35\}
\end{aligned}
$$

\subsection{Jalur Terpendek (Shortest Path)}

\subsubsection{Penerapan Algoritma Semut}

Penerapan algoritma semut dalam menyelesaikan permasalahan jalur optimasi dalam kehidupan seharihari mencakup beberapa persoalan (Triandi, 2012) diantaranya: Quadratic Assignment Problem (QAP), Job-shop Scheduling Problem (JSP), Vehicle Routing Problem (VRP) dan Traveling Salesman Problem (TSP).

\subsubsection{Algoritma Semut}

Menurut Ambarsari (2017) perilaku dari algortima semut diadopsi dari koloni semut yang secara alami mampu menemukan rute terpendek dalam perjalanan mencari makanan dari sarang ke sumber makanan. Hal ini dapat dilakukan karena semut meninggalkan feromon pada saat mencari sumber makanan. Berikut ini ilustrasi perjalanan semut dalam menemukan sumber makan (Gambar 2).
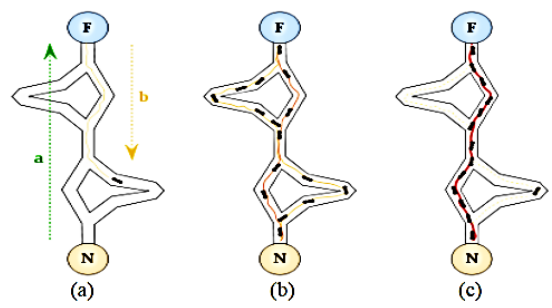

Gambar 2. Perjalanan semut menemukan sumber makanan

\subsubsection{Langkah Penyelesaian Algoritma Semut}

Secara umum langkah-langkah dalam AS adalah (Bronson, 1882; Zukhri, 2005):

Langkah 1:

a. Inisialisasi harga parameter- parameter algoritma.

b. Inisialisasi kota pertama setiap semut.

Langkah 2: Pengisian kota pertama ke dalam tabu list.

Langkah 3: Penyusunan rute kunjungan setiap semut ke setiap kota. Langkah 4:

a. Perhitungan panjang rute setiap semut.

b. Pencarian rute terpendek.

c. Perhitungan perubahan harga intensitas jejak kaki semut antar kota.

Langkah 5:

a. Perhitungan harga intensitas jejak kaki semut antar kota untuk siklus berikutnya.

b. Reset harga perubahan intensitas jejak kaki semut antar kota.

Langkah 6: Pengosongan tabu list, dan ulangi langkah 2 jika diperlukan.

\section{Metode}

Alur rancang bangun penelitian yang diimplimentasikan dalam bentuk kerangka pemikiran seperti digambarkan berikut (Gambar 3):

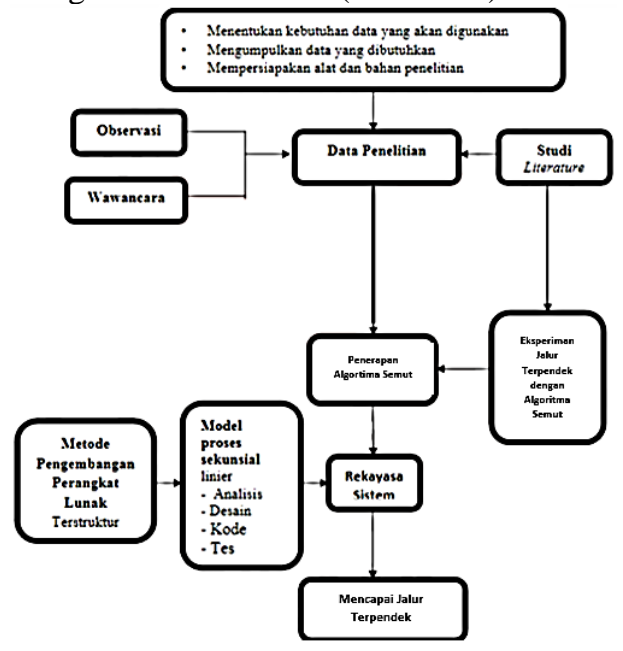

Gambar 3. Kerangka Pemikiran

\section{Hasil dan Pembahasan}

\subsection{Hasil Penelitian}

Pada penelitian ini peneliti memilih 8 (delapan) titik-titik lokasi dari data Penentuan Distribusi Jalur pipa pengolahan air bersih pada Pada PKPAM Kep. Riau. Dimana titik mewakili tempat. Pemilihan titiktitik lokasi dipilih langsung oleh peneliti sebanyak 8 (delapan) titik dengan mempertimbangkan kondisi eksisting jalan yang ada sekarang. Tiap titik di simpan di setiap persimpangan dimana titik $\mathbf{N}$ menjadi titik tujuan dan titik A merupakan titik awal. Berikut beberapa lokasi titik dari data Penentuan Distribusi Jalur pipa pengolahan air bersih pada Pada PKPAM Kep. Riau yang dijadikan sampel dalam penelitian ini yaitu:

$\begin{array}{llll}\mathrm{V} 1 & =\text { Titik A } & \mathrm{V}_{5} & =\text { Titik E } \\ \mathrm{V}_{2} & =\text { Titik B } & \mathrm{V}_{6} & =\text { Titik F } \\ \mathrm{V}_{3} & =\text { Titik C } & \mathrm{V}_{7} & =\text { Titik G } \\ \text { V4 } & =\text { Titik D } & \text { V8 } & =\text { Titik N }\end{array}$

Dimana site map Distribusi Jalur pipa pengolahan air bersih dapat diperlihatkan pada Gambar 4 dibawah ini:

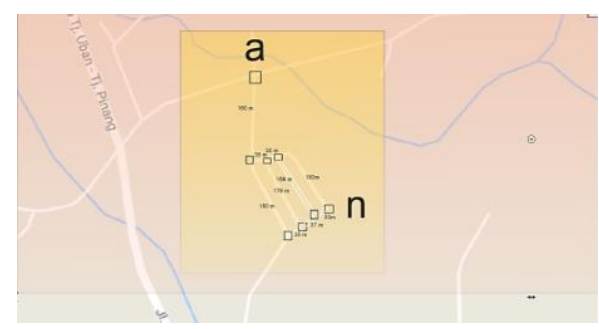

Gambar 4. Peta 8 titik lokasi Jalur pipa pengolahan air bersih 
Langkah pertama dalam menyelesaikan kasus ini yakni dengan menggambarkan titik-titik lokasi Jalur pipa pengolahan air bersih menjadi titik-titik yang ada dalam graf kemudian bobot sisi dalam graf merupakan jarak antara titik-titik lokasi Jalur pipa pengolahan air bersih (Gambar 5).

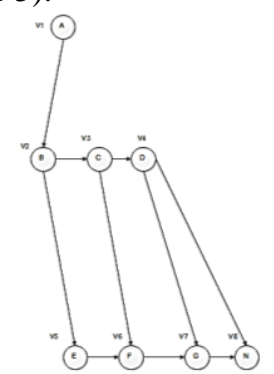

Gambar 5. Graf lengkap 8 titik lokasi tujuan

Berdasarkan data yang didapatkan maka dapat disusun jarak Jalur pipa pengolahan air bersih (meter) dari masing-masing titik pada Tabel 1 sebagai berikut:

Tabel 1. Jarak jalur pipa pengolahan air bersih (meter) 8 titik

\begin{tabular}{lcccccccc}
\hline $\begin{array}{l}\text { Jarak } \\
\text { (meter) }\end{array}$ & $\mathrm{V} 1$ & $\mathrm{~V} 2$ & $\mathrm{~V} 3$ & $\mathrm{~V} 4$ & $\mathrm{~V} 5$ & $\mathrm{~V} 6$ & $\mathrm{~V} 7$ & $\mathrm{~V} 8$ \\
\hline V1 & 0 & 160 & & & & & & \\
V2 & 160 & 0 & 35 & & 180 & & & \\
V3 & & 35 & 0 & 30 & & 179 & & \\
V4 & & & 30 & 0 & & & 169 & 180 \\
V5 & & 180 & & & 0 & 35 & & \\
V6 & & & 179 & & 35 & 0 & 37 & \\
V7 & & & & 169 & & 37 & 0 & 30 \\
V8 & & & & 180 & & & 30 & 0 \\
\hline
\end{tabular}

Berdasarkan tabel 1 maka graf pada gambar 5 dapat diberi bobot sesuai jarak yang diberikan pada tabel 1 dengan model graf pada Gambar 6 sebagai berikut:

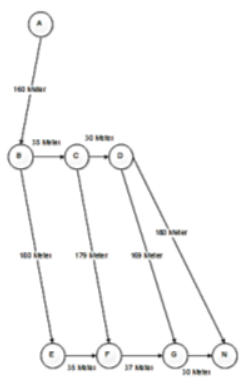

Gambar 6. Graf lengkap 8 titik Jalur pipa air bersih

Selanjutnya yaitu menggunakan algoritma semut untuk mendapatkan jalur terpendek (optimal). Langkah pertama yang dilakukan yaitu inisialisasi harga parameter-parameter algoritma, parameterparameter yang digunakan yaitu:

$\beta=1,00$

$\alpha=1,00$

$\dot{\mathrm{p}}=0,01$

Banyak semut $(k)=8$

pheromon awal yakni dengan menggunakan rumus (1)

$\tau i j=\tau 0=\frac{k}{C \text { greedy }}$
Perhitungan dengan menggunakan algoritma greedy yaitu:

1. Memilih titik awal yaitu titik V1

2. V1 memiliki jalur di V2 masing-masing dengan jarak (160). Selanjutnya diambil jarak minimal atau paling kecil sehingga yang terpilih yaitu V2 sehingga diperoleh jalur pertama yaitu $\mathrm{V} 1 \rightarrow \mathrm{V} 2$

3. Melakukan cara yang sama dengan langkah kedua dimana dimulai dari titik

yang terpilih yaitu V2. V2 memiliki jalur di V3 dan V5 masing-masing dengan jarak (35) dan (180). Selanjutnya diambil jarak minimal atau paling kecil sehingga yang terpilih yaitu V3 sehingga diperoleh jalur kedua yaitu $\mathrm{V} 1 \rightarrow \mathrm{V} 2 \rightarrow \mathrm{V} 3$

4. Melakukan cara yang sama dengan langkah ketiga dimana dimulai dari titik yang terpilih yaitu V3 . V3 memiliki jalur di V6 dan V4 masing-masing dengan jarak (179) dan (30) Selanjutnya mengambil jarak minimal atau paling kecil sehingga yang terpilih yaitu V4 sehingga diperoleh jalur ketiga yaitu $\mathrm{V} 1 \rightarrow \mathrm{V} 2 \rightarrow \mathrm{V} 3 \rightarrow \mathrm{V} 4$

5. Melakukan cara yang sama dengan langkah keempat dimana dimulai dari titik yang terpilih yaitu V4 . V4 memiliki jalur di V7 dan V8 masingmasing dengan jarak (169) dan (180). Selanjutnya mengambil jarak minimal atau paling kecil sehingga yang terpilih yaitu V7 sehingga diperoleh jalur keempat yaitu $\mathrm{V} 1 \rightarrow \mathrm{V} 2 \rightarrow \mathrm{V} 3 \rightarrow \mathrm{V} 4 \rightarrow \mathrm{V} 7$

6. Melakukan cara yang sama dengan langkah kelima dimana dimulai dari titik

yang terpilih yaitu V7. V7 memiliki jalur di V4 dan V8 masing-masing dengan jarak (169) dan (30). Selanjutnya mengambil jarak minimal atau paling kecil sehingga yang terpilih yaitu V8. Sehingga diperoleh jalur keempat yaitu $\mathrm{V} 1 \rightarrow \mathrm{V} 2 \rightarrow \mathrm{V} 3 \rightarrow \mathrm{V} 4 \rightarrow \mathrm{V} 7 \rightarrow \mathrm{V} 8$

7. Selanjutnya karena sudah tidak ada titik lagi maka titik yang terakhir yaitu V8 sehingga diperoleh jalur $\mathrm{V} 1 \rightarrow \mathrm{V} 2 \rightarrow \mathrm{V} 3 \rightarrow \mathrm{V} 4 \rightarrow \mathrm{V} 7 \rightarrow \mathrm{V} 8$. sehingga diperoleh jarak minimal Cgreedy $=160+35+30$ $+169+30=424$.

Selanjutnya dari algoritma Greedy diatas sehingga didapatkan feromon awal

$$
\tau i j=\tau 0=\frac{k}{c \text { greedy }}=\frac{8}{424}=0,01887
$$

Langkah kedua yaitu mencari nilai visibilitas antara titik dengan menggunakan rumus(2):

$\varphi i j=\frac{1}{d i j}$

dimana $\varphi i j$ merupakan jarak antara titik yang telah diketahui.

Sehingga didapatkan:

$\varphi 1,2=\frac{1}{d 1,2}=\frac{1}{160}=0,00625$

$\varphi 2,1=\frac{1}{d 2,1}=\frac{1}{160}=0,00625$

$\varphi 2,3=\frac{1}{d 2,3}=\frac{1}{35}=0,02857$

$\varphi 2,5=\frac{1}{d 2,5}=\frac{1}{180}=0,00556$

Dengan cara yang sama diperoleh nilai visibilitas antara titik pada Tabel 2 berikut: 
Tabel 2. Visibilitas antara titik

\begin{tabular}{cccccccccc}
\hline \multicolumn{1}{c}{$\varphi i j$} & $\mathrm{~V} 1$ & & $\mathrm{~V} 2$ & $\mathrm{~V} 3$ & $\mathrm{~V} 4$ & $\mathrm{~V} 5$ & $\mathrm{~V} 6$ & $\mathrm{~V} 7$ & \multicolumn{1}{c}{$\mathrm{V} 8$} \\
\hline V1 & 0 & 0,00625 & 0 & 0 & 0 & 0 & 0 & 0 \\
V2 & 0,00625 & 0 & 0,02857 & 0 & 0,00556 & 0 & 0 & 0 \\
V3 & 0 & 0,02857 & 0 & 0,03333 & 0 & 0,00559 & 0 & 0 \\
V4 & 0 & 0 & 0,03333 & 0 & 0 & 0 & 0,00592 & 0,00556 \\
V5 & 0 & 0,00556 & 0 & 0 & 0 & 0,02857 & 0 & 0 \\
V6 & 0 & 0 & 0,00559 & 0 & 0,02857 & 0 & 0,02703 & 0 \\
V7 & 0 & 0 & 0 & 0,00592 & 0 & 0,02703 & 0 & 0,03333 \\
V8 & 0 & 0 & 0 & 0,00556 & 0 & 0 & 0,03333 & 0 \\
\hline
\end{tabular}

Langkah selanjutnya yaitu menyusun rute perjalanan ke setiap titik lokasi. Dalam hal ini peneliti menggunakan semut sebagai istilah dalam menemukan distribusi jalur pipa pengolahan air bersih tercepat. Dalam hal ini Semut yang terdistribusi kesemua titik akan melakukan perjalanan dari titik pertama masing-masing sebagai titik asal dan titik lain sebagai titik tujuan. Setelah itu semut melakukan perjalanan secara acak dengan pertimbangan tidak pernah di lalui sebelumnya. Perjalanan semut berlangsung terus menerus sampai semua titik telah dikunjungi dan membentuk suatu jalur. Berikut perhitungan probabilitas untuk siklus ke-1 $(N C=1)$

\subsection{Siklus ke-1 $(N C=1)$}

A. Semut ke-1 (kl)

Tabu list $=\mathrm{V} 1$

$$
p \frac{k}{i j}=\frac{[\tau i j]^{\alpha} *[\tau i j]^{\beta}}{\sum_{k^{\prime} \in\left\{N-t a b u_{k}\right\}}\left[\tau i k^{\prime}\right]^{\alpha} *\left[\tau i k^{\prime}\right]^{\beta}}=\text { untuk } j(3)
$$

$p \frac{k}{i j}=0$, untuk $\mathrm{j}$ lainnya dengan i sebagai indeks kota asal dan $\mathrm{j}$ sebagai indeks kota tujuan.

$\sum_{k^{\prime} \in\left\{N-t a b u_{k}\right\}}\left[\tau i k^{\prime}\right]^{\alpha} *\left[\tau i k^{\prime}\right]^{\beta}=$ $(0,01887)^{1} .(0,00625)^{1}=0,000118$

Titik V1 $=p \frac{1}{i j}=0$

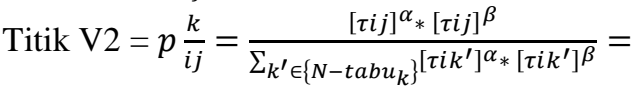

$$
=\frac{(0,01887)^{\wedge} 1 \cdot(0,00625)^{\wedge} 1}{0,000118}=1
$$

Titik V3 $=p \frac{1}{i j}=0$

Titik V4 $=p \frac{1}{i j}=0$

Titik V $5=p \frac{1}{i j}=0$

Titik V6 $=p \frac{1}{i j}=0$

Titik V7 $=p \frac{1}{i j}=0$

Titik V8 $=p \frac{1}{i j}=0$

Probabilitas ke-1 antara titik V1 ke titik lainnya tertera pada Tabel 3 berikut ini.

Tabel 3. Probabilitas semut ke-1 antara titik V1 ke titik lainnya

\begin{tabular}{lllllllll}
\hline Ket & V1 & V2 & V3 & V4 & V5 & V6 & V7 & V8 \\
\hline V1 & 0 & 1 & 0 & 0 & 0 & 0 & 0 & 0 \\
Kum & 0 & 1 & 1 & 1 & 1 & 1 & 1 & 1 \\
\hline
\end{tabular}

Bilangan random yang dibangkitkan antara 0-1 dengan menggunakan fungsi Excel yaitu Rand() maka terpilih 0,7982 sehingga titik yang terpilih yaitu V2 sehingga Tabu list menjadi $\mathrm{V} 1 \rightarrow \mathrm{V} 2$. Lakukan langkah yang sama untuk semut ke-2 yang dimulai dari titik V2.

B. Semut ke-2 (k2)

Tabu list $=\mathrm{V} 2$

$$
p \frac{k}{i j}=\frac{[\tau i j]^{\alpha} *[\tau i j]^{\beta}}{\sum_{k^{\prime} \in\left\{N-t a b u_{k}\right\}}\left[\tau i k^{\prime}\right]^{\alpha} *\left[\tau i k^{\prime}\right]^{\beta}}=\text { untuk } j(4)
$$

$p \frac{k}{i j}=0$, untuk $\mathrm{j}$ lainnya dengan i sebagai indeks kota asal dan $\mathrm{j}$ sebagai indeks kota tujuan.

$\sum_{k^{\prime} \in\left\{N-\text { tabu }_{k}\right\}}\left[\tau i k^{\prime}\right]^{\alpha} *\left[\tau i k^{\prime}\right]^{\beta}=$

$(0,01887)^{1} \cdot(0,00625)^{1}+(0,01887)^{1} \cdot(0,02857)^{1}+$ $(0,01887)^{1} \cdot(0,00556)^{1}=0,000762$

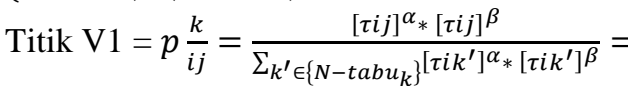

$$
=\frac{(0,01887)^{\wedge} 1 \cdot(0,00625)^{\wedge} 1}{0,000762}=0,1548
$$

Titik V2 $=p \frac{k}{i j}=0$

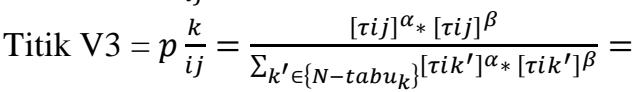

$$
\begin{aligned}
& =\frac{(0,01887)^{\wedge} 1 \cdot(0,02857)^{\wedge} 1}{0,000762}=0,7076
\end{aligned}
$$

Titik V4 $=p \frac{1}{i j}=0$

Titik V5 $=p \frac{k}{i j}=\frac{[\tau i j]^{\alpha} *[\tau i j]^{\beta}}{\sum_{k^{\prime} \in\left\{N-t a b u_{k}\right\}}\left[\tau i k^{\prime}\right]^{\alpha} \cdot\left[\tau i k^{\prime}\right]^{\beta}}=$

$$
=\frac{(0,01887)^{\wedge} 1 \cdot(0,00556)^{\wedge} 1}{0,000762}=0,1376
$$

Titik V6 $=p \frac{1}{i j}=0$

Titik V7 $=p \frac{1}{i j}=0$

Titik V8 $=p \frac{1}{i j}=0$

Probabilitas ke-2 antara titik V2 ke titik lainnya tertera pada Tabel 4 berikut ini.

Tabel 4. Probabilitas semut ke-2 antara titik V2 ke titik lainnya

\begin{tabular}{ccccc}
\hline Ket & V1 & V2 & V3 & V4 \\
\hline V2 & 0,1548 & 0 & 0,7076 & 0 \\
Kumulatif & 0,1548 & 0,1548 & 0,8624 & 0,8624 \\
\hline \multicolumn{7}{c}{} \\
\hline Ket & V5 & V6 & V7 & V8 \\
\hline V2 & 0,1376 & 0 & 0 & 0 \\
Kumulatif & 1 & 1 & 1 & 1 \\
\hline
\end{tabular}


Bilangan random yang dibangkitkan antara 0-1 dengan menggunakan fungsi Excel yaitu Rand() maka terpilih 0,7759 sehingga titik yang terpilih yaitu V3 sehingga Tabu list menjadi V2 $\rightarrow \mathrm{V} 3$. Lakukan langkah yang sama untuk semut ke-3 yang dimulai dari titik V3.

C. Semut ke-3 $(k 3)$

Tabu list $=\mathrm{V} 3$

$$
p \frac{k}{i j}=\frac{[\tau i j]^{\alpha} *[\tau i j]^{\beta}}{\sum_{k^{\prime} \in\left\{N-t a b u_{k}\right\}}\left[\tau i k^{\prime}\right]^{\alpha} *\left[\tau i k^{\prime}\right]^{\beta}}=\text { untuk } j(5)
$$

$p \frac{k}{i j}=0$, untuk $\mathrm{j}$ lainnya dengan i sebagai indeks kota asal dan $\mathrm{j}$ sebagai indeks kota tujuan.

$\sum_{k^{\prime} \in\left\{N-\text { tabu }_{k}\right\}}\left[\tau i k^{\prime}\right]^{\alpha} *\left[\tau i k^{\prime}\right]^{\beta}=$

$(0,01887)^{1} \cdot(0,02857)^{1}+(0,01887)^{1} \cdot(0,03333)^{1}+$

$(0,01887)^{1} \cdot(0,0559)^{1}=0,001274$

Titik V1 $=p \frac{1}{i j}=0$

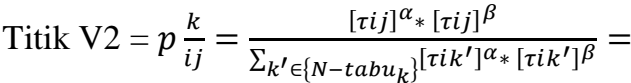

$$
=\frac{(0,01887)^{\wedge} 1 \cdot(0,02857)^{\wedge} 1}{0,001274}=0,4233
$$

Titik V3 $=p \frac{1}{i j}=0$

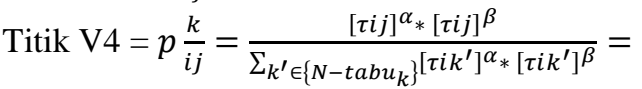

$$
=\frac{(0,01887)^{\wedge} 1 \cdot(0,03333)^{\wedge} 1}{0,001274}=0,4939
$$

Titik V5 $=p \frac{1}{i j}=0$

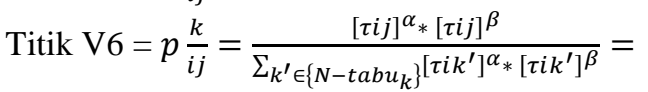

$$
=\frac{(0,01887)^{\wedge} 1 \cdot(0,00559)^{\wedge} 1}{0,001274}=0,0828
$$

Titik V7 $=p \frac{1}{i j}=0 ;$ Titik V8 $=p \frac{1}{i j}=0$

Probabilitas ke-3 antara titik V3 ke titik lainnya tertera pada Tabel 5 berikut ini.

Tabel 5. Probabilitas semut ke-3 antara titik V3 ke titik lainnya

\begin{tabular}{ccccc}
\hline Ket & V1 & V2 & V3 & V4 \\
\hline V3 & 0 & 0,4233 & 0 & 0,4939 \\
Kumulatif & 0 & 0,4233 & 0,4233 & 0,9172 \\
\hline \multicolumn{1}{r}{ Ket } & V5 & V6 & V7 & V8 \\
\hline V3 & 0 & 0,0828 & 0 & 0 \\
Kumulatif & 0,9172 & 1 & 1 & 1
\end{tabular}

Bilangan random yang dibangkitkan antara 0-1 dengan menggunakan fungsi Excel yaitu Rand() maka terpilih 0,9711 sehingga titik yang terpilih yaitu V6 sehingga Tabu list menjadi V3 $\rightarrow \mathrm{V} 6$. Lakukan langkah yang sama untuk semut ke-4 yang dimulai dari titik V4.

D. Semut ke-4 (k4)

Tabu list $=$ V4 $p \frac{k}{i j}=\frac{[\tau i j]^{\alpha} *[\tau i j]^{\beta}}{\sum_{k^{\prime} \in\left\{N-t a b u_{k}\right\}}\left[\tau i k^{\prime}\right]^{\alpha} *\left[\tau i k^{\prime}\right]^{\beta}}=$ untuk $j(6)$
$\in\left\{N-t a b u_{k}\right\}$

$p \frac{k}{i j}=0$, untuk j lainnya dengan i sebagai indeks kota asal dan j sebagai indeks kota tujuan.

$\sum_{k^{\prime} \in\left\{N-\text { tabu }_{k}\right\}}\left[\tau i k^{\prime}\right]^{\alpha} *\left[\tau i k^{\prime}\right]^{\beta}=$

$(0,01887)^{1} \cdot(0,03333)^{1}+(0,01887)^{1} \cdot(0,00592)^{1}+$

$(0,01887)^{1} \cdot(0,00556)^{1}=0,000845$

Titik V1 $=p \frac{1}{i j}=0$

Titik V2 $=p \frac{k}{i j}=0$

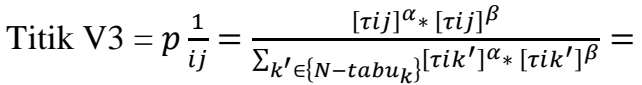
$=\frac{(0,01887)^{\wedge} 1 \cdot(0,03333)^{\wedge} 1}{0,000845}=0,743$

Titik V4 $=p \frac{1}{i j}=0$

Titik V5 $=p \frac{1}{i j}=0$

Titik V6 $=p \frac{1}{i j}=0$

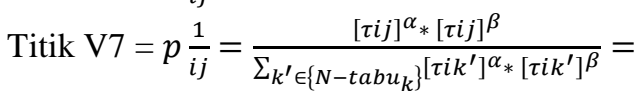
$=\frac{(0,01887)^{\wedge} 1 \cdot(0,00592)^{\wedge} 1}{0,000845}=0,1321$

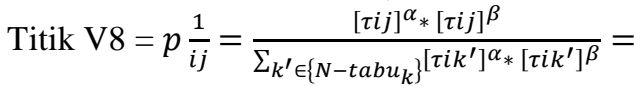
$=\frac{(0,01887)^{\wedge} 1 \cdot(0,00556)^{\wedge} 1}{0,000845}=0,1240$

Probabilitas ke-4 antara titik V4 ke titik lainnya tertera pada Tabel 6 berikut ini.

Tabel 6. Probabilitas semut ke-4 antara titik V4 ke titik lainnya

\begin{tabular}{ccccc}
\hline Ket & V1 & V2 & V3 & V4 \\
\hline V4 & 0 & 0 & 0,7439 & 0 \\
Kumulatif & 0 & 0 & 0,7439 & 0,7439 \\
\hline \multicolumn{7}{c}{} \\
\hline Ket & V5 & V6 & V7 & V8 \\
\hline V4 & 0 & 0 & 0,1321 & 0,1240 \\
Kumulatif & 0,7439 & 0,7439 & 0,876 & 1 \\
\hline
\end{tabular}

Bilangan random yang dibangkitkan antara 0-1 dengan menggunakan fungsi Excel yaitu Rand() maka terpilih 0,9083 sehingga titik yang terpilih yaitu V8 sehingga Tabu list menjadi V4 $\rightarrow$ V8. Lakukan langkah yang sama untuk semut ke-5 yang dimulai dari titik V5.

E. Semut ke-5 (k5)

Tabu list $=$ V5

$$
\begin{aligned}
& p \frac{k}{i j}=\frac{[\tau i j]^{\alpha} *[\tau i j]^{\beta}}{\sum_{k^{\prime} \in\left\{N-t a b u_{k}\right\}}\left[\tau i k^{\prime}\right]^{\alpha} *\left[\tau i k^{\prime}\right]^{\beta}}=\operatorname{untuk} j(7) \\
& \in\left\{N-t a b u_{k}\right\}
\end{aligned}
$$

$p \frac{k}{i j}=0$, untuk j lainnya dengan i sebagai indeks kota asal dan $\mathrm{j}$ sebagai indeks kota tujuan. 
$\sum_{k^{\prime} \in\left\{N-t a b u_{k}\right\}}\left[\tau i k^{\prime}\right]^{\alpha} *\left[\tau i k^{\prime}\right]^{\beta}=$

$(0,01887)^{1} \cdot(0,00556)^{1}+(0,01887)^{1} \cdot(0,02703)^{1}=$ 0,000644

Titik V1 $=p \frac{1}{i j}=0$

Titik V2 $=p \frac{k}{i j}=\frac{[\tau i j]^{\alpha}{ }^{\alpha}[\tau i j]^{\beta}}{\sum_{k^{\prime} \in\left\{N-t a b u_{k}\right\}}^{\left.\left[\tau i k^{\prime}\right]^{\alpha}\right]_{*}\left[\tau i k^{\prime}\right]^{\beta}}}=$ $=\frac{(0,01887)^{\wedge} 1 \cdot(0,00556)^{\wedge} 1}{0,000644}=0,1628$

Titik V3 $=p \frac{1}{i j}=0$

Titik V4 $=p \frac{1}{i j}=0$

Titik V5 $=p \frac{1}{i j}=0$

Titik V6 $=p \frac{1}{i j}=\frac{[\tau i j]^{\alpha} *[\tau i j]^{\beta}}{\sum_{k^{\prime} \in\left\{N-t a b u_{k}\right\}}\left[\tau i k^{\prime}\right]^{\alpha_{*}\left[\tau i k^{\prime}\right]^{\beta}}}=$ $=\frac{(0,01887)^{\wedge} 1 \cdot(0,02857)^{\wedge} 1}{0,000644}=0,8372$

Titik V7 $=p \frac{1}{i j}=0$

Titik V8 $=p \frac{1}{i j}=0$

Probabilitas ke-5 antara titik V5 ke titik lainnya tertera pada Tabel 7 berikut ini.

Tabel 7. Probabilitas semut ke-5 antara titik V5 ke titik lainnya

\begin{tabular}{ccccc}
\hline Ket & V1 & V2 & V3 & V4 \\
\hline V5 & 0 & 0,1628 & 0 & 0 \\
Kumulatif & 0 & 0,1628 & 0,1628 & 0,1628 \\
\hline \multicolumn{1}{r}{ Ket } & V5 & V6 & V7 & V8 \\
\hline V5 & 0 & 0,8372 & 0 & 0 \\
Kumulatif & 0,1628 & 1 & 1 & 1 \\
\hline
\end{tabular}

Bilangan random yang dibangkitkan antara 0-1 dengan menggunakan fungsi Excel yaitu Rand() maka terpilih 0,8654 sehingga titik yang terpilih yaitu V6 sehingga Tabu list menjadi V5 $\rightarrow$ V6. Lakukan langkah yang sama untuk semut ke-6 yang dimulai dari titik V6.

F. Semut ke-6 (k6)

Tabu list $=\mathrm{V} 6$

$$
p \frac{k}{i j}=\frac{[\tau i j]^{\alpha} *[\tau i j]^{\beta}}{\sum_{k^{\prime} \in\left\{N-t a b u_{k}\right\}}\left[\tau i k^{\prime}\right]^{\alpha} *\left[\tau i k^{\prime}\right]^{\beta}}=\text { untuk } j(8)
$$

$p \frac{k}{i j}=0$, untuk j lainnya dengan i sebagai indeks kota asal dan $\mathrm{j}$ sebagai indeks kota tujuan.

$\sum_{k^{\prime} \in\left\{N-\text { tabu }_{k}\right\}}\left[\tau i k^{\prime}\right]^{\alpha} *\left[\tau i k^{\prime}\right]^{\beta}=$

$(0,01887)^{1} \cdot(0,00559)^{1}+(0,01887)^{1} \cdot(0,02857)^{1}+$

$(0,01887)^{1} \cdot(0,02703)^{1}=0,001155$

Titik V1 $=p \frac{1}{i j}=0$

Titik V2 $=p \frac{k}{i j}=0$

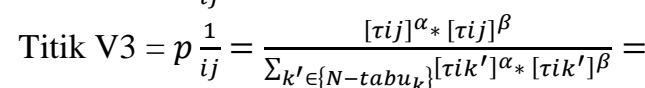

$$
=\frac{(0,01887)^{\wedge} 1 \cdot(0,00559)^{\wedge} 1}{0,001155}=0,0913
$$

Titik V4 $=p \frac{1}{i j}=0$

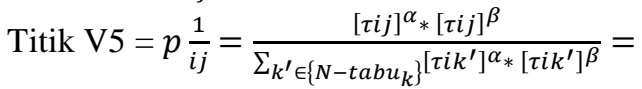
$=\frac{(0,01887)^{\wedge} 1 \cdot(0,02857)^{\wedge} 1}{0,001155}=0,4670$

Titik V6 $=p \frac{1}{i j}=0$

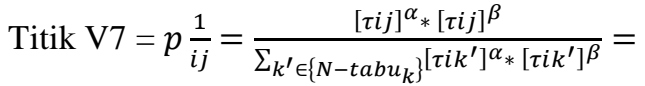

$$
=\frac{(0,01887)^{\wedge} 1 \cdot(0,02703)^{\wedge} 1}{0,001155}=0,4417
$$

Titik V8 $=p \frac{1}{i j}=0$

Probabilitas ke-6 antara titik V6 ke titik lainnya tertera pada Tabel 8 berikut ini.

Tabel 8. Probabilitas semut ke-6 antara titik V6 ke titik lainnya

\begin{tabular}{ccccc}
\hline Ket & V1 & V2 & V3 & V4 \\
\hline V6 & 0 & 0 & 0,0913 & 0 \\
Kumulatif & 0 & 0 & 0,0913 & 0,0913 \\
\hline \multicolumn{7}{c}{ Ket } & V5 & V6 & V7 & V8 \\
\hline V6 & 0,4670 & 0 & 0,4417 & 0 \\
Kumulatif & 0,5583 & 0,5583 & 1 & 1 \\
\hline
\end{tabular}

Bilangan random yang dibangkitkan antara 0-1 dengan menggunakan fungsi Excel yaitu Rand() maka terpilih 0,6355 sehingga titik yang terpilih yaitu V7 sehingga Tabu list menjadi V6 $\rightarrow$ V7. Lakukan langkah yang sama untuk semut ke-7 yang dimulai dari titik V7.

G. Semut ke-7 (k7)

Tabu list $=\mathrm{V} 7$

$p \frac{k}{i j}=\frac{[\tau i j]^{\alpha} *[\tau i j]^{\beta}}{\sum_{k^{\prime} \in\left\{N-t a b u_{k}\right\}}\left[\tau i k^{\prime}\right]^{\alpha} *\left[\tau i k^{\prime}\right]^{\beta}}=\operatorname{untuk} j(9)$

$p \frac{k}{i j}=0$, untuk $\mathrm{j}$ lainnya dengan i sebagai indeks kota asal dan j sebagai indeks kota tujuan.

$\sum_{k^{\prime} \in\left\{N-\text { tabu }_{k}\right\}}\left[\tau i k^{\prime}\right]^{\alpha} *\left[\tau i k^{\prime}\right]^{\beta}=$

$(0,01887)^{1} \cdot(0,00592)^{1}+(0,01887)^{1} \cdot(0,02703)^{1}+$

$(0,01887)^{1} \cdot(0,03333)^{1}=0,001251$

Titik V1 $=p \frac{1}{i j}=0$

Titik V2 $=p \frac{k}{i j}=0$

Titik V3 $=p \frac{1}{i j}=0$

Titik V4 $=p \frac{1}{i j}=\frac{[\tau i j]^{\alpha}{ }^{\alpha}[\tau i j]^{\beta}}{\sum_{k^{\prime} \in\left\{N-t a b u_{k}\right\}}\left[\tau i k^{\prime}\right]^{\alpha}{ }^{\alpha}\left[\tau i k^{\prime}\right]^{\beta}}=$ $=\frac{(0,01887)^{\wedge} 1 \cdot(0,00592)^{\wedge} 1}{0,001251}=0,0893$

Titik V5 $=p \frac{1}{i j}=0$

Titik V6 $=p \frac{1}{i j}=\frac{[\tau i j]^{\alpha}[\tau i j]^{\beta}}{\sum_{k^{\prime} \in\left\{N-t a b u_{k}\right\}}\left[\tau i k^{\prime}\right]^{\alpha}{ }^{\alpha}\left[\tau i k^{\prime}\right]^{\beta}}=$

$$
=\frac{(0,01887)^{\wedge} 1 \cdot(0,02703)^{\wedge} 1}{0,001251}=0,4078
$$

Titik V7 $=p \frac{1}{i j}=0$ 


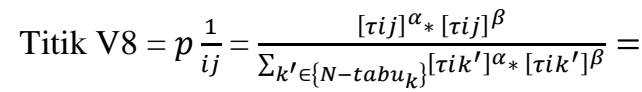

$$
=\frac{(0,01887)^{\wedge} 1 \cdot(0,03333)^{\wedge} 1}{0,001251}=0,5029
$$

Probabilitas ke-7 antara titik V7 ke titik lainnya tertera pada Tabel 9 berikut ini.

Tabel 9. Probabilitas semut ke-7 antara titik V7 ke titik lainnya

\begin{tabular}{ccccc}
\hline Ket & V1 & V2 & V3 & V4 \\
\hline V7 & 0 & 0 & 0 & 0,0893 \\
Kumulatif & 0 & 0 & 0 & 0,0893 \\
\hline \multicolumn{1}{c}{ Ket } & V5 & V6 & V7 & V8 \\
\hline V7 & 0 & 0,4078 & 0 & 0,5029 \\
Kumulatif & 0,0893 & 0,4971 & 0,4971 & 1 \\
\hline
\end{tabular}

Bilangan random yang dibangkitkan antara 0-1 dengan menggunakan fungsi Excel yaitu Rand() maka terpilih 0,6966 sehingga titik yang terpilih yaitu V8 sehingga Tabu list menjadi V7 $\rightarrow$ V8.

Dikarenakan tujuan Jalur pipa pengolahan air bersih adalah V8 atau Titik N, maka proses kunjungan semut berakhir pada semut ke 7 . Setelah didapatkan semua rute untuk perjalanan semut yang pertama maka dapat disusun Tabel 10.

Langkah selanjutnya yaitu melanjutkan perjalanan kedua dengan cara yang sama dengan sebelumnya yang dimana semut ke-1 $(k l)$ diawali dari titik yang terpilih dalam hal ini V2, semut ke-2 $(k 2)$ diawali dari titik V3, semut ke-3 $(k 3)$ diawali dari titik V6. Semut ke-4 $(k 4)$ diawali dari titik V8, semut ke-5 (k5) diawali dari titik V6, semut ke-6 ( $k 6)$ diawali dari titik V7, semut ke-7 ( $k 7$ ) diawali dari titik V8. Dalam kasus ini, tidak semua rute dapat dijadikan solusi jalur optimal, ada beberapa rute yang dapat dijadikan solusi jalur optimal yakni :
1. $\mathrm{V} 1 \rightarrow \mathrm{V} 2 \rightarrow \mathrm{V} 5 \rightarrow \mathrm{V} 6 \rightarrow \mathrm{V} 7 \rightarrow \mathrm{V} 8$
2. $\mathrm{V} 1 \rightarrow \mathrm{V} 2 \rightarrow \mathrm{V} 3 \rightarrow \mathrm{V} 6 \rightarrow \mathrm{V} 7 \rightarrow \mathrm{V} 8$
3. $\mathrm{V} 1 \rightarrow \mathrm{V} 2 \rightarrow \mathrm{V} 3 \rightarrow \mathrm{V} 4 \rightarrow \mathrm{V} 7 \rightarrow \mathrm{V} 8$
4. $\mathrm{V} 1 \rightarrow \mathrm{V} 2 \rightarrow \mathrm{V} 3 \rightarrow \mathrm{V} 4 \rightarrow \mathrm{V} 8$

\subsection{Siklus ke-2 $(N C=2)$}

A. Semut ke-1 (kl)

$\beta=1,00$

$\alpha=1,00$

$\dot{\mathrm{p}}=0,01$
Tabu list $=\mathrm{V} 2$

Dilakukan proses update pheromone $(\tau)$ lokal

$\tau i j($ baru $)=(1-\dot{\mathrm{p}}) \tau i j+\Delta \tau i j k$

$=(1-0,01) *(0,1548)+((0,01 *(1 / 0,1548))$

$=0,21785$

$p \frac{k}{i j}=\frac{[\tau i j]^{\alpha} *[\tau i j]^{\beta}}{\sum_{k^{\prime} \in\left\{N-t a b u_{k}\right\}}\left[\tau i k^{\prime}\right]^{\alpha} *\left[\tau i k^{\prime}\right]^{\beta}}$

$=u n t u k j$

$\in\left\{N-t a b u_{k}\right\}$

$p \frac{k}{i j}=0$, untuk j lainnya dengan i sebagai indeks kota asal dan j sebagai indeks kota tujuan.

$\sum_{k^{\prime} \in\left\{N-\text { tabu }_{k}\right\}}\left[\tau i k^{\prime}\right]^{\alpha} *\left[\tau i k^{\prime}\right]^{\beta}=$

$(0,21785)^{1} \cdot(0,00625)^{1}+(0,21785)^{1} \cdot(0,02857)^{1}+$

$(0,21785)^{1} \cdot(0,00556)^{1}=0,008796$

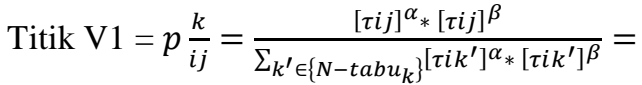

$$
=\frac{(0,21785)^{\wedge} 1 \cdot(0,00625)^{\wedge} 1}{0,008796}=0,1548
$$

Titik V2 $=p \frac{k}{i j}=0$

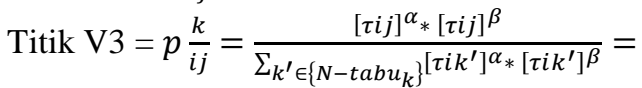

$$
=\frac{(0,21785)^{\wedge} 1 \cdot(0,02857)^{\wedge} 1}{0,008796}=0,7076
$$

Titik V4 $=p \frac{1}{i j}=0$

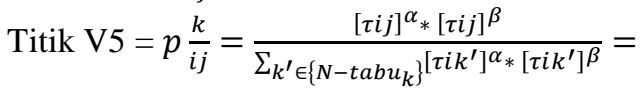

$$
=\frac{(0,21785)^{\wedge} 1 \cdot(0,00556)^{\wedge} 1}{0,008796}=0,1376
$$

Titik V6 $=p \frac{1}{i j}=0$

Titik V7 $=p \frac{1}{i j}=0$

Titik V8 $=p \frac{1}{i j}=0$

Probabilitas semut ke-1 antara titik V2 ke titik lainnya tertera pada Tabel 11 .

Tabel 11. Probabilitas semut ke-1 antara titik V2 ke titik lainnya

\begin{tabular}{ccccc}
\hline Ket & V1 & V2 & V3 & V4 \\
\hline V2 & 0,1548 & 0 & 0,7076 & 0 \\
Kumulatif & 0,1548 & 0,1548 & 0,8624 & 0,8624 \\
\hline \multicolumn{7}{c}{} \\
\hline Ket & $\mathrm{V} 5$ & $\mathrm{~V} 6$ & $\mathrm{~V} 7$ & $\mathrm{~V} 8$ \\
\hline V2 & 0,1376 & 0 & 0 & 0 \\
Kumulatif & 1 & 1 & 1 & 1 \\
\hline
\end{tabular}

$\underline{\text { Tabel 10. Perjalanan pertama semut }}$

\begin{tabular}{ccccccccccccc}
\hline \multirow{2}{*}{ Semut } & Titik & \multicolumn{9}{c}{ Probabilitas } & \multicolumn{2}{c}{ Titik } \\
& Awal & V1 & V2 & V3 & V4 & V5 & V6 & V7 & V8 & Terpilih \\
List
\end{tabular}


Bilangan random yang dibangkitkan antara 0-1 dengan menggunakan fungsi Excel yaitu Rand() maka terpilih 0,4295 sehingga titik yang terpilih yaitu V3 sehingga Tabu list menjadi $\mathrm{V} 1 \rightarrow \mathrm{V} 2 \rightarrow \mathrm{V} 3$. Lakukan langkah yang sama untuk semut ke-1 yang dimulai dari titik V3.

\section{B. Semut ke-1 (k3)}

Tabu list $=\mathrm{V} 3$

$$
\begin{gathered}
p \frac{k}{i j}=\frac{[\tau i j]^{\alpha} *[\tau i j]^{\beta}}{\sum_{k^{\prime} \in\left\{N-t a b u_{k}\right\}}\left[\tau i k^{\prime}\right]^{\alpha} *\left[\tau i k^{\prime}\right]^{\beta}} \\
=\text { untuk } j
\end{gathered}
$$

$\in\left\{N-t a b u_{k}\right\}$

$p \frac{k}{i j}=0$, untuk j lainnya dengan i sebagai indeks kota asal dan $\mathrm{j}$ sebagai indeks kota tujuan.

$\sum_{k^{\prime} \in\left\{N-t_{a b u}\right\}}\left[\tau i k^{\prime}\right]^{\alpha} *\left[\tau i k^{\prime}\right]^{\beta}=$

$(0,21785)^{1} \cdot(0,02857)^{1}+(0,21785)^{1} \cdot(0,03333)^{1}+$

$(0,21785)^{1} \cdot(0,0559)^{1}=0,014703$

Titik V1 $=p \frac{1}{i j}=0$

Titik V2 $=p \frac{k}{i j}=\frac{[\tau i j]^{\alpha} *[\tau i j]^{\beta}}{\sum_{k^{\prime} \in\left\{N-t a b u_{k}\right\}}\left[\tau i k^{\prime}\right]^{\alpha} *\left[\tau i k^{\prime}\right]^{\beta}}=$

$$
=\frac{(0,21785)^{\wedge} 1 \cdot(0,02857)^{\wedge} 1}{0,014703}=0,4233
$$

Titik V3 $=p \frac{1}{i j}=0$

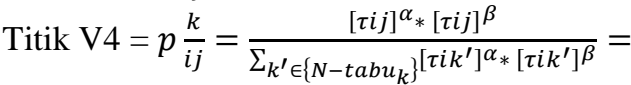

$$
=\frac{(0,21785)^{\wedge} 1 \cdot(0,03333)^{\wedge} 1}{0,014703}=0,4939
$$

Titik V5 $=p \frac{1}{i j}=0$

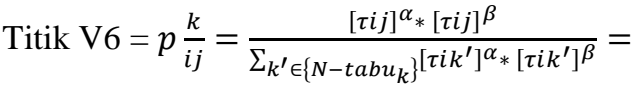

$$
=\frac{(0,21785)^{\wedge} 1 \cdot(0,00559)^{\wedge} 1}{0,014703}=0,0828
$$

Titik V7 $=p \frac{1}{i j}=0$

Titik V8 $=p \frac{1}{i j}=0$

Probabilitas semut ke-1 antara titik V3 ke titik lainnya tertera pada Tabel 12 .

Tabel 12. Probabilitas semut ke-1 antara titik V3 ke titik lainnya

\begin{tabular}{ccccc}
\hline Ket & V1 & V2 & V3 & V4 \\
\hline V3 & 0 & 0,4233 & 0 & 0,4939 \\
Kumulatif & 0 & 0,4233 & 0,4233 & 0,9172 \\
\hline \multicolumn{7}{c}{} & & & \\
\hline Ket & V5 & V6 & V7 & V8 \\
\hline V3 & 0 & 0,0828 & 0 & 0 \\
Kumulatif & 0,9172 & 1 & 1 & 1 \\
\hline
\end{tabular}

Bilangan random yang dibangkitkan antara 0-1 dengan menggunakan fungsi Excel yaitu Rand() maka terpilih 0,5356 sehingga titik yang terpilih yaitu V4 sehingga Tabu list menjadi $\mathrm{V} 1 \rightarrow \mathrm{V} 2 \rightarrow \mathrm{V} 3 \rightarrow \mathrm{V} 4$. Lakukan langkah yang sama untuk semut ke-1 yang dimulai dari titik V4.
C. Semut ke-1 (k4)

$\mathrm{Tabu}$ list $=\mathrm{V} 4$

$$
\begin{gathered}
p \frac{k}{i j}=\frac{[\tau i j]^{\alpha} *[\tau i j]^{\beta}}{\sum_{k^{\prime} \in\left\{N-t a b u_{k}\right\}}\left[\tau i k^{\prime}\right]^{\alpha} *\left[\tau i k^{\prime}\right]^{\beta}} \\
=\text { untukj }
\end{gathered}
$$

$\in\left\{N-t a b u_{k}\right\}$

$p \frac{k}{i j}=0$, untuk $\mathrm{j}$ lainnya dengan i sebagai indeks kota asal dan $\mathrm{j}$ sebagai indeks kota tujuan.

$\sum_{k^{\prime} \in\left\{N-\text { tabu }_{k}\right\}}\left[\tau i k^{\prime}\right]^{\alpha} *\left[\tau i k^{\prime}\right]^{\beta}=$

$(0,21785)^{1} \cdot(0,03333)^{1}+(0,21785)^{1} \cdot(0,00592)^{1}+$

$(0,21785)^{1} \cdot(0,00556)^{1}=0,009761$

Titik V1 $=p \frac{1}{i j}=0$

Titik V2 $=p \frac{k}{i j}=0$

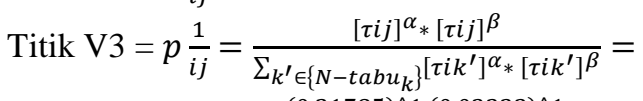
$=\frac{(0,21785)^{\wedge} 1 \cdot(0,03333)^{\wedge} 1}{0,009761}=0,7439$

Titik V4 $=p \frac{1}{i j}=0$

Titik V5 $=p \frac{1}{i j}=0$

Titik V6 $=p \frac{1}{i j}=0$

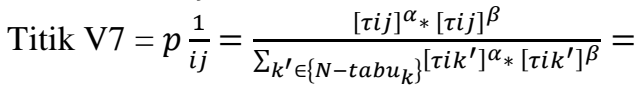
$=\frac{(0,21785)^{\wedge} 1 \cdot(0,00592)^{\wedge} 1}{0,009761}=0,1321$

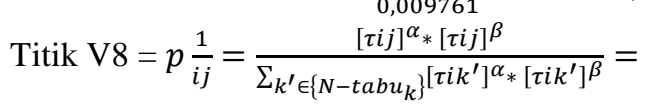
$=\frac{(0,21785)^{\wedge} 1 \cdot(0,00556)^{\wedge} 1}{0,009761}=0,1240$

Probabilitas semut ke-1 antara titik V4 ke titik lainnya tertera pada Tabel 13 .

Tabel 13. Probabilitas semut ke-1 antara titik V4 ke titik lainnya

\begin{tabular}{ccccc}
\hline Ket & V1 & V2 & V3 & V4 \\
\hline V4 & 0 & 0 & 0,7439 & 0 \\
kumulatif & 0 & 0 & 0,7439 & 0,7439 \\
\hline \multicolumn{7}{c}{ Ket } & V5 & V6 & V7 & V8 \\
\hline V4 & 0 & 0 & 0,1321 & 0 \\
kumulatif & 0,7439 & 0,7439 & 0,876 & 1 \\
\hline
\end{tabular}

Bilangan random yang dibangkitkan antara 0-1 dengan menggunakan fungsi Excel yaitu Rand() maka terpilih 0,9418 sehingga titik yang terpilih yaitu V8 sehingga Tabu list menjadi $\mathrm{V} 1 \rightarrow \mathrm{V} 2 \rightarrow \mathrm{V} 3 \rightarrow \mathrm{V} 4 \rightarrow \mathrm{V} 8$.

\subsection{Pembahasan}

Siklus pertama telah selesai dilakukan dan didapatkan pembaharuan feromon, langkah selanjutnya mencari rute yang lebih baik lagi pada siklus kedua. Jika terdapat rute yang lebih baik dibanding siklus pertama dalam hal ini memiliki panjang rute yang lebih kecil maka feromon akan diperbaharui kembali, namun ketika siklus kedua tidak lebih baik dari pada siklus pertama maka yang 
diambil adalah rute yang ada pada siklus pertama. Begitupun untuk siklus ketiga, keempat dan seterusnya sampai mencapai NC max atau batas iterasi yang ditentukan. Pada pencarian dengan cara manual hanya terbatas untuk siklus pertama atau iterasi pertama $(\mathrm{NC}=1)$ sehingga diperoleh rute Jalur pipa pengolahan air bersih 1 ). $\mathrm{V} 1 \rightarrow \mathrm{V} 2 \rightarrow \mathrm{V} 3 \rightarrow \mathrm{V} 4 \rightarrow \mathrm{V} 8$ dengan panjang diperoleh rute Jalur pipa pengolahan air bersih 405 meter; 2). $\mathrm{V} 1 \rightarrow \mathrm{V} 2 \rightarrow \mathrm{V} 3 \rightarrow \mathrm{V} 4 \rightarrow \mathrm{V} 7 \rightarrow \mathrm{V} 8 \quad$ dengan panjang diperoleh rute Jalur pipa pengolahan air bersih 424 meter; 3). $\mathrm{V} 1 \rightarrow \mathrm{V} 2 \rightarrow \mathrm{V} 3 \rightarrow \mathrm{V} 6 \rightarrow \mathrm{V} 7 \rightarrow \mathrm{V} 8$ dengan panjang diperoleh rute Jalur pipa pengolahan air bersih 441 meter; dan 4). $\mathrm{V} 1 \rightarrow \mathrm{V} 2 \rightarrow \mathrm{V} 5 \rightarrow \mathrm{V} 6 \rightarrow \mathrm{V} 7 \rightarrow \mathrm{V} 8 \quad$ dengan panjang diperoleh rute Jalur pipa pengolahan air bersih 442 meter.

\section{Kesimpulan}

Kesimpulan yang dapat ditarik pada pencarian jalur pipa pengolahan air bersih dengan menggunakan algoritma semut pada satuan kerja pengembangan kinerja pengolahan air minum di Kepulauan Riau adalah diperolehnya jalur terpendek antara dua siklus A dan $\mathrm{N}$ dimana pipa hanya melewati jalur terpendek pada rute $3(\mathrm{~V} 1 \rightarrow \mathrm{V} 2 \rightarrow \mathrm{V} 3 \rightarrow \mathrm{V} 6 \rightarrow \mathrm{V} 7 \rightarrow \mathrm{V} 8)$ dengan panjang pipa 441 meter. Diharapkan penelitian selanjutnya dapat menggunakan algoritma pencarian yang berbeda untuk mendapatkan hasil terbaik dari pencarian rute terdekat.

\section{Daftar Pustaka}

Ambarsari, E.W., 2017. Modifikasi algoritma semut untuk optimasi probabilitas pemilihan node dalam penentuan jalur terpendek. Jurnal String, 2(2), 193-200.

Biggs, N., 1986. The traveling salesman problem a guided tour of combinatorial optimization. Bulletin of the London Mathematical Society, 18(5), 514-515.

Bronson, R., 1882. Theory and Problems of Operations Research. New York: McGraw Hill.

Greco, F., 2008. Algoritma semut untuk penyelesaian travelling salesman problem. Jurnal Ilmiah MATRIK 10(2), 183-194.

Ikhsan, J., 2016. Penerapan algoritma semut untuk optimisasi rute penjemputan barang pada tempat jasa penitipan sementara lion express, Jurnal Ilmiah Sarjana Mahasiswa UMRAH, (Vol. 1).

Ismail, A.A., Herdjunanto, S., 2012. Penerapan algoritma ant system dalam menemukan jalur optimal pada traveling salesman problem (tsp) dengan kekangan kondisi jalan. Jnteti, 1(3),43-47.

Munir, R., 2005. Matematika Diskrit. Edisi ketiga. In Bandung: Informatika.

Nugroho, K., 2015. Penggunaan algoritma semut untuk penentuan optimisasi jalur tim marketing.
INFOKAM, 2(9), 92-95.

Putrama, A., Windarto, A.P., 2018. Analisis dalam menentukan produk bri syariah terbaik berdasarkan dana pihak ketiga menggunakan AHP. CESS (Journal of Computer Engineering System and Science), 3(1), 60-64.

Sadewo, M. G., Windarto, A. P., Hartama, D., 2017. Penerapan datamining pada populasi daging ayam ras pedaging di indonesia berdasarkan provinsi menggunakan k-means clustering. Jurnal Nasional Informatika dan Teknologi Jaringan, 2(1), 60-67.

Siregar, M.N.H., 2017. Neural network analysis with backpropogation in predicting human development index ( HDI ) component by regency / city in North Sumatera. Internatinal Journal Of Informations Systems and Technologyy (IJISTECH), 1(1), 22-33.

Solikhun, Windarto, A.P., Handrizal, M.Fauzan., 2017. Jaringan saraf tiruan dalam memprediksi sukuk negara ritel berdasarkan kelompok profesi dengan backpropogation dalam mendorong laju pertumbuhan ekonomi. Kumpulan Jurnal Ilmu Komputer (KLIK), 4(2), 184-197.

Sumijan, Windarto, A.P., Muhammad, A., Budiharjo, 2016. Implementation of neural networks in predicting the understanding level of students subject. Internat. Journal of Software Engineering and Its Applications, 10(10), 189-204.

Triandi, B., 2012. Penemuan Jalur Terpendek Dengan Algoritma Ant Colony. Csrid, 4(2), 73-80.

Windarto, A.P., 2017a. Implementation of data mining on rice imports by major country of origin using algorithm using k-means clustering method. International Journal of Artificial Intelligence Research, 1(2), 26-33.

Windarto, A.P., 2017b. Penerapan Data Mining Pada Ekspor Buah-Buahan Menurut Negara Tujuan Menggunakan K-Means Clustering. Techno.COM, 16(4), 348-357.

Windarto, A.P., Dewi, L.S., Hartama, D., 2017. Implementation of artificial intelligence in predicting the value of indonesian oil and gas exports with bp algorithm. International Journal of Recent Trends in Engineering \& Research (IJRTER), 3(10), 1-12.

Yuwono, B., Aribowo, A.S., Wardoyo, S.B., 2009. Implementasi algoritma koloni semut pada proses pencarian jalur terpendek jalan protokol di Kota Yogyakarta. Seminar Nasional Informatika 2009, 111-120.

Zer, P. P. P. A. N. W. F. I. R. H., Windarto, A.P., 2018. Analisis pemilihan rekomendasi produk terbaik prudential berdasarkan jenis asuransi jiwa berjangka untuk kecelakaan menggunakan metode analytic hierarchy process. Journal of Computer Engineering System and Science 3(1), 78-82.

Zukhri, Z., 2005. Analisis algoritma semut untuk pemecahan masalah penugasan. SNASTI 2005, 47-51. 